Claremont Colleges

Scholarship@Claremont

WM Keck Science Faculty Papers

W.M. Keck Science Department

1-1-2009

\title{
Bats and Bell Holes: The Microclimatic Impact of Bat Roosting, Using a Case Study from Runaway Bay Caves, Jamaica
}

Joyce Lundberg

Carleton University

Donald A. McFarlane

Claremont McKenna College; Pitzer College; Scripps College

\section{Recommended Citation}

Joyce Lundberg, Donald A. McFarlane, Bats and bell holes: The microclimatic impact of bat roosting, using a case study from Runaway Bay Caves, Jamaica, Geomorphology, Volume 106, Issues 1-2, 1 May 2009, Pages 78-85, ISSN 0169-555X, http://dx.doi.org/ 10.1016/j.geomorph.2008.09.022.

This Article is brought to you for free and open access by the W.M. Keck Science Department at Scholarship @ Claremont. It has been accepted for inclusion in WM Keck Science Faculty Papers by an authorized administrator of Scholarship @ Claremont. For more information, please contact scholarship@cuc.claremont.edu. 


\title{
Bats and bell holes: The microclimatic impact of bat roosting, using a case study from Runaway Bay Caves, Jamaica
}

\author{
Joyce Lundberg $^{\mathrm{a}, *}$, Donald A. McFarlane ${ }^{\mathrm{b}}$ \\ a Department of Geography and Environmental Studies, Carleton University, Ottawa, ON, Canada K1S 5B6 \\ ${ }^{\mathrm{b}}$ W. M. Keck Science Center, The Claremont Colleges, Claremont CA 91711, USA
}

\section{A R T I C L E I N F O}

\section{Article history:}

Received 4 July 2007

Received in revised form 24 June 2008

Accepted 18 September 2008

Available online $\mathrm{xxxx}$

\section{Keywords:}

Bell hole

Jamaica

Bat

Microclimate

Niche construction

\begin{abstract}
A B S T R A C T
The microclimatic effect of bats roosting in bell holes (blind vertical cylindrical cavities in cave roofs) in Runaway Bay Caves, Jamaica, was measured and the potential impact of their metabolism on dissolution modelled. Rock temperature measurements showed that bell holes with bats get significantly hotter than those without bats during bat roosting periods (by an average of $1.1^{\circ} \mathrm{C}$ ). The relationship is clearest for bell holes with more than about $300 \mathrm{~g}$ aggregate bat body mass and for bell holes that are moderately wide and deep, of W:D ratio between 0.8 and 1.6. Measurement of temperature decay after abandonment showed that rock temperature returns to normal each day during bat foraging periods. Metabolic activity from a typical population of $400 \mathrm{~g}$ bat ( 10 individuals) yields $41 \mathrm{~g}$ of $\mathrm{CO}_{2}, 417.6 \mathrm{~kJ}$ of heat, and $35.6 \mathrm{~g}$ of $\mathrm{H}_{2} \mathrm{O}$ in each 18 hour roost period, and could produce a water film of $\sim 0.44 \mathrm{~mm}$, that is saturated with $\mathrm{CO}_{2}$ at $\sim 5 \%$. The resultant rock dissolution is estimated at $\sim 0.005 \mathrm{~cm}^{3} \mathrm{CaCO}_{3}$ per day. The metabolic heat ensures that the focus of dissolution remains vertical regardless of geological controls. A typical bell hole $1 \mathrm{~m}$ deep may be formed in some 50,000 years by this mechanism alone. Addition of other erosional mechanisms, such as direct bacterial bio-erosion, or the formation of exfoliative organo-rock complexes, would accelerate the rate of formation. The hypothesis is developed that bell holes are initiated and formed by bat-mediated condensation corrosion and are governed by geographic distribution of clustering bats and their roosting behaviour.
\end{abstract}

(c) 2008 Elsevier B.V. All rights reserved.

\section{Introduction}

Niche construction, the expression of organisms' adaptation to their environment and modification of that environment, is a topic that is causing some lively debate (see news report: Jones, 2005). Dawkins (2004) suggests that only one type - direct modification where an organism engineers its own environment - can be truly labelled as "niche construction". The other type - indirect modification of the environment as a byproduct of the organism's way of life should have a distinct term, which he suggests as "niche changing".

Here we report on a simple study of a small but intriguing example of "niche changing" in tropical caves. The study is of the microclimatic effect of bats roosting in bell holes of Jamaica. We explore the extent of the microclimatic modification and the potential impact of that change on the location, mode, and rates of limestone dissolution. From this we develop a model of bat-mediated condensation corrosion to explain bell hole formation. This is a contribution to the on-going (but poorly data-supported) debate in karst studies about how these features develop.

\footnotetext{
* Corresponding author. Tel.: +1 613520 2600x2571; fax: +1 6135204301 .

E-mail addresses: joyce_lundberg@carleton.ca (J. Lundberg), dmcfarlane@jsd.claremont.edu (D.A. McFarlane).
}

Bell holes are cylindrical, cigar-shaped, blind cavities extending vertically upwards into the roofs of caves, generally less than $1 \mathrm{~m}$ in diameter and $2 \mathrm{~m}$ in height (Tarhule-Lips and Ford, 1997, 1998a; Lauritzen and Lundberg, 2000; Lundberg, 2005). Their long axes are always vertical, and cross sections close to perfect circles. They curve smoothly from the plane of the cave roof up the almost-vertical sides up to a rounded top (Fig. 1). Tarhule-Lips and Ford (1998a), one of the few publications offering rigorously measured data, report that the bell holes of Cayman Brac vary from 0.2 to $5.7 \mathrm{~m}$ in depth but the majority are less than $3 \mathrm{~m}$. Basal diameters are 0.25 to $1.3 \mathrm{~m}$. The basic shape is very similar: diameter to depth ratio is generally $\leq 1$, the central axis is vertical, the angle of the upwards taper of side walls averages $10^{\circ}$ from the vertical, and the apex diameter is generally 0.3 to $0.5 \mathrm{~m}$. One of the more intriguing and highly significant characteristics of bell holes is that they have no apparent geological control: no relationship with bedding planes, joint planes, faults, or sedimentary structures. Indeed a single bell hole may be observed (Miller, 2006; and personal observation) to cut smoothly through both speleothem and the neighbouring bedrock.

Their geographic distribution appears to be limited to the humid tropics (Tarhule-Lips and Ford, 1998a). The only suggestion of bell holes outside of the humid tropics seems to be in an unpublished master's thesis by Dogwiler (1998). The local distribution is a pseudorandom or polygonal pattern in the entrance zones of certain caves 


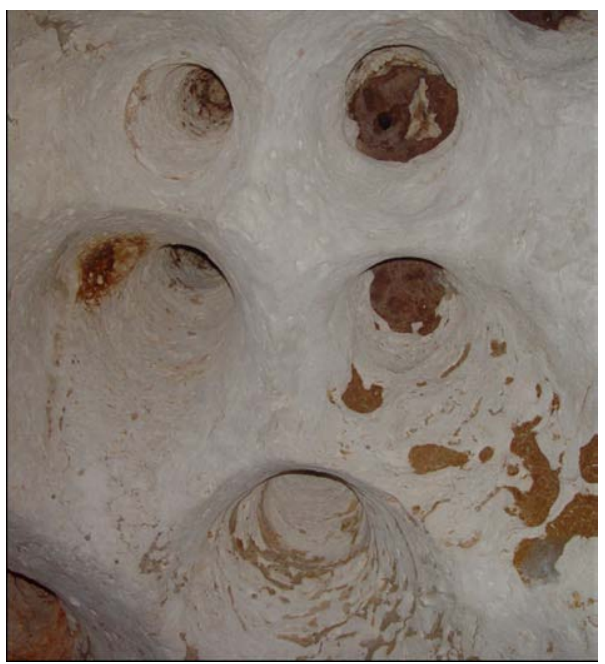

Fig. 1. Bell holes in Runaway Bay Caves, looking directly up into the roof. These bell holes are approximately $50 \mathrm{~cm}$ deep and $30 \mathrm{~cm}$ basal diameter. Note the brown exfoliative crusts. (For interpretation of the references to colour in this figure legend, the reader is referred to the web version of this article.)

(Lauritzen et al., 1997; Tarhule-Lips and Ford, 1998a). Lauritzen and Lundberg (2000) interpret the pattern as a competitive process, filling suitable available space. In light of this study in Jamaica, the present authors would modify that interpretation to include the influence of random or non-random pre-existing surface form, such as phreatic scalloping: in the caves of Jamaica that we studied, the local distribution of the bell holes is strongly governed by the distribution of the pre-existing scallops or pockets (Fig. 2). We would further modify the interpretation to include the influence of non-random biological activity, as explained below.

\subsection{Bell hole formation}

Their mode of formation is perplexing. They are clearly differentiated from simple ceiling pockets (phreatic or vadose) by the complete absence of association with fractures or feedwater routes and they show no evidence of water flowing down the sides or dripping from the roof. As early as 1966, Wilford noted this for the bell holes of Sarawak. Dogwiler (1998), on the observation that they could not be vadose, assumed that bell holes must therefore be phreatic, a theory discussed (and doubted) by Wilford (1966). The extraordinarily neat vertical axes and elongate, narrow shapes that ignore geological controls, and the restriction to cave ceilings argue against a phreatic origin. It is obvious that the bell hole is a post-speleogenetic feature superimposed on the cave cross section after passage excavation (Lauritzen et al., 1997; Miller, 2006) or on newly exposed surfaces after passage collapse (Miller, 1981). Thus a phreatic origin would require a post-speleogenetic raising of the water level to fill the cave - a situation not geographically possible in most sites. From Puerto Rico, Miller (2006) reports that the vadose parts of some caves have bell holes while the phreatic parts, accessible to cave divers only, show no bell holes; however, neither do the open vadose chambers and passages behind a $5 \mathrm{~cm}$ air space. This provides a rather strong argument for the lack of relevance of either phreatic or normal vadose processes. Unfortunately Miller's reference is simply an abstract so no further details are available, and the data behind these assertions cannot be examined. Tarhule-Lips and Ford (1998a) convincingly argue that the bell holes of Cayman Brac cannot have formed in subaqueous conditions, either phreatic or through sporadic flooding. The environment of formation is thus subaerial. They suggest that dissolution occurs in the thin film of condensation water that is prevalent in the entrance zones of the caves studied. This process may be enhanced (or not) by microbiological activity, and may be complicated by photosynthetic activity. Although they speculate at length, it is not clear in their model how this process is limited to discrete points as is required to produce bell holes.

One of the long-standing theories is that bell holes are somehow caused by bat activity (King-Webster and Kenny, 1958; Dwyer and Hamilton-Smith, 1975). Anecdotal evidence always seems to centre on the association of bats with bell holes (Miller, 2006, goes so far as to define bell holes as "biogenic (bat) features") - but bats are rather common in caves and it is obvious that the majority of caves that have bats do not have bell holes. Thus, the association is not obligate. The effect of bat action was discussed as early as 1958 by King-Webster and Kenny; in this case the action was presumed to be largely mechanical from bat claws during roosting. The implication is that bell

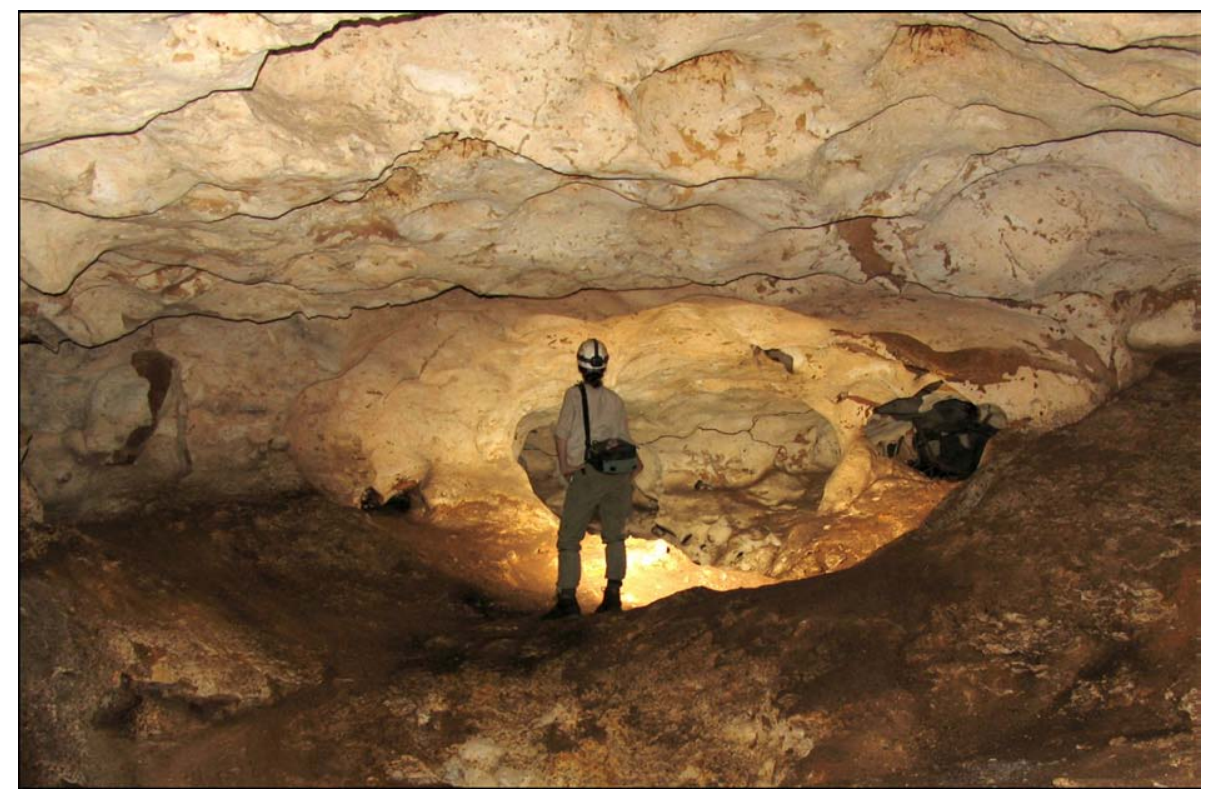

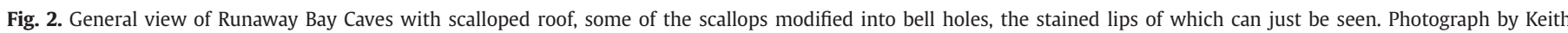
Christensen, reproduced with permission. 
holes should be restricted to relatively soft rocks, as was the case for King-Webster and King's study. Miller (1981) speculates that the acidity of bat urine may be a potential agent of corrosion. We question this supposed acidity of urine: while data could not be found on the $\mathrm{pH}$ of bat urine, the normal $\mathrm{pH}$ of rat urine is very close to neutral at 6.7 (Kadlubar et al., 1981). Tarhule-Lips and Ford (1998a), noting the absence of claw marks on the walls of bell holes and the problem of transfer of urine from hanging bat to bell hole ceiling, discount these hypotheses. Miller (2006) offers many observations and ideas that, in this short abstract, are not substantiated. These include the restriction of bell holes to areas of the caves accessible to bats, the presence of hydroxylapatite in brown stains on the rock. He suggests that bedrock is chemically altered by bat faeces and urine, as well as physical contact with claws. We agree that bedrock certainly is known to be altered by contact with excreta (in the case of hydroxylapatite, it is the faeces that contain $~ 98 \%$ of the phosphate: Ige et al., 2006), but the physical problem of upward dissemination of faeces and the distributional problem of restriction of corrosion to discrete and very distinct spots on the ceiling remain unsolved.

This leads to the present research. We decided to measure the effect of the mere presence of bats on the microclimate of the bell holes, because in a limestone system microclimate may significantly impact dissolution.

\subsection{Background to research}

Literature abounds on endangered bat species of temperate areas and their habitat. For example, hibernating bats seek out environments of low ambient temperature, typically $2{ }^{\circ} \mathrm{C}-8{ }^{\circ} \mathrm{C}$, in order to minimize metabolic rates during torpor (TutTarhule-Lipse, 1975; Ransome, 1990). These bats employ strategies to avoid raising roost microclimate temperatures, such as clustering species seeking colder caves (McNab, 1974). However, few studies have investigated the complexities of small-scale roost microclimate dynamics (Bakken and Kunz, 1988), especially in the tropics.

The biological activity of small mammals in relatively confined spaces can produce enough heat, water vapour, and carbon dioxide to cause detectable changes in the micro-climate. Kunz $(1974,1980)$ notes that occupied bat roosts are generally warmer than equivalent unoccupied roosts. These microclimate effects are particularly pronounced in certain warm-temperate caves hosting very large populations of bats such as the Brazilian Free-Tailed bat, Tadarida brasiliensis (Kunz and Robson, 1995), and in tropical caves (RodríguezDurán, 1998). Here, we investigate the potential of bat-mediated microclimates to contribute to the formation of bell holes in tropical karst caves.

\section{Methods}

The research had two foci. The first was to measure the effect of bat presence on air and rock temperature in bell holes, the second was to model the potential impact of known metabolic activity on a confined body of air and rock surface.

Green Grotto/Runaway Bay Caves, Jamaica $\left(18^{\circ} 27^{\prime} 37.7^{\prime \prime}\right.$ N, $77^{\circ} 22^{\prime}$ 26.7" E, altitude $20 \mathrm{~m}$, about $0.5 \mathrm{~km}$ from the modern coastline), was chosen because it has numerous bell holes, the roof is relatively low and thus accessible, and, being a tourist cave, the bats are reasonably habituated to human activity and thus were expected to be less easily disturbed than in a non-tourist cave. The research was done during the daytime (i.e., during bat roosting) in January 2005 with permission from the management of Runaway Bay Caves.

The cave is formed at the top of the Montpelier beds of the Upper Eocene-Lower Miocene White Limestone (Sweeting, 1958). This unit is of chalky limestone. The cave is a three-dimensional, spongework, phreatic maze within a 20 m vertical range between the cliff top and modern sea level. It has several daylight holes where the ceilings of phreatic chambers have collapsed. Some parts reach water table. Bat guano covers most of the floor area and has, in the past, been mined for fertilizer. All areas are accessible, to bats as well as humans, and bell holes are ubiquitous. Bell holes were not limited to twilit zones (in contrast to the observations of Tarhule-Lips and Ford, 1998a and others). They were present in, and sampled from, both dimly-lit photic zones and dark zones; in all cases no light reached the bell holes themselves. All parts of the cave were sampled except for those areas with deep water (about $8 \%$ of the cave).

In order to distinguish bell holes from random negative features, bell holes were defined as negative forms in the ceiling with a width: depth ratio of $\leq 2$ (according to Tarhule-Lips and Ford, 1998a, most bell holes have $W$ :D ratios of $\leq 1.0$ ). Sampling was limited in each chamber to those bell holes that could be measured before the bats departed. Sites were approached quietly to avoid disturbing the bats and rock temperature was measured immediately, using an infra-red remote thermometer (brand name- Raytek ST60: spatial precision $13.3 \mathrm{~cm}$ at $4 \mathrm{~m}$; thermal precision $\pm 0.27{ }^{\circ} \mathrm{C} 2$ sigma, calibrated on limestone at $33^{\circ} \mathrm{C}$ against NIST certified precision thermometer). In each case the number of bats was counted and the species identified. The temperature of the rock surface was measured at the top of the bell hole (with care to avoid direct measurements on bats) and just outside the lip for the ambient temperature. This gave the difference in temperature between inside and outside the bell hole. In order to determine if bell holes without bats, as well as bell holes with bats, have detectably different micro-climates from the rest of the cave (they may simply trap warm air because they are negative forms), bell holes were chosen in pairs: one with bats and its partner without bats, matched as far as possible for size and shape. While sampling had to be limited to the available bell holes, we tried to sample a range of small to large bell holes, and with few to many bats in each.

Dimensions were measured with a Leica Geosystems Laser Rangefinder (precision $\pm 3 \mathrm{~mm}$ ). Height of roof and height of bell hole at centre were measured (giving also depth of hole). Width at lip was measured where roof could be accessed and estimated for higher regions. Depth and width:depth ratios indicate the general shape of the bell holes. Summary statistics for morphological measures of the 56 bell holes are shown in Table 1 .

We also measured the time required for an abandoned bell hole to cool down to ambient temperature.

The limitations of the empirical research are relatively minor. Care was taken to avoid bat disturbance, but, obviously, the possibility of bat relocation immediately prior to the observation period must be acknowledged. This would give two potential errors: the one is a cool bell hole with bats that had just arrived, the other is a warm bell hole from which bats had just retreated.

\section{Results}

\subsection{Empirical observations: temperatures, bats and bell hole characteristics}

Only two species were common in the studied part of the cave: Monophyllus redmani and Artibeus jamaicensis. The body mass of $M$. redmani is $\sim 15 \mathrm{~g}$, and of $A$. jamaicensis $\sim 40 \mathrm{~g}$. (Pedersen and Genoways, 1996; Rivera-Marchand and Rodríguez-Durán, 2001; Vaughan-Jennings et al., 2004).

\section{Table 1}

Summary statistics of bell hole morphology $(n=56)$

\begin{tabular}{llcl}
\hline & Width $(\mathrm{cm})$ & Depth $(\mathrm{cm})$ & W/D \\
\hline Average & 35 & 62 & 0.78 \\
St. dev. & 10 & 36 & 0.49 \\
Median & 30 & 57 & 0.68 \\
Min & 20 & 20 & 0.15 \\
Max & 60 & 173 & 2.00 \\
\hline
\end{tabular}


Table 2

Summary statistics of bell hole temperatures

\begin{tabular}{llll}
\hline & Average & St. Dev. & $\mathrm{n}$ \\
\hline Temperature at lip of empty bell holes & 25.28 & 0.48 & 28 \\
Temperature top of empty bell holes & 25.39 & 0.51 & \\
Temperature at lip of bat-occupied bell holes & 25.29 & 0.41 & 28 \\
Temperature top of bat-occupied bell holes & 26.39 & 0.78 & \\
\hline
\end{tabular}

Average temperature at lips and tops of bell holes with no bats and bell holes with bats was compared (Table 2 ) and tested for statistically significant differences (Table 3 ). A very simple pattern emerged. The lip temperature for bell holes with or without bats is not significantly different. The temperature at the tops of bell holes without bats is not significantly different from the lip temperature. The temperature at the tops of bell holes with bats is significantly higher than the temperature at the lip. The temperature at the tops of bell holes with bats is significantly higher than those without bats.

So, the simple message is that bell holes with bats do get significantly hotter than those without bats. However, the relationship is not simple. Other ways of comparing bell holes with and without bats highlight some of the complexities.

Bat mass has significant impact on absolute temperature at the tops of bell holes and on the temperature differences between lip and top, but the relationship is best expressed in bell holes with more bats. Ambient temperature for all bell hole lips averages $25.3{ }^{\circ} \mathrm{C}$, varying $(2 \sigma)$ from 24.4 to $26.2{ }^{\circ} \mathrm{C}$ depending on distance from entrances. The presence of only a few bats raises the temperature a little, but only to the higher end of the ambient temperature range. If bat mass is below $\sim 300 \mathrm{~g}$, then the impact on bell hole temperature is not significant $\left(p=3.5, r^{2}=0.30\right)$. When all data are included, the regression between bat mass and temperature difference shows a significant relationship with $p=0.003$, but an $r^{2}$ of only 0.28 . However, the relationship improves to an $r^{2}$ of 0.86 and $p$ of 0.0003 when only the larger bat masses (>300 g) are considered (Fig. 3). Thus the temperature difference between tops and lips shows the clearest relationship for bell holes with more than about 10 bats; below this, the bat mass is too small to create very big temperature differences.

Another complexity is that the shape of the bell hole is important. The shape of the bell hole has an effect both on the number of bats that will occupy it and on the retention of heat generated. Width to depth ratio (W:D) indicates the relative length. The width at lip is relatively less variable (co-efficient of variation of $30 \%$ ) than the depth (coefficient of variation of 63\%); therefore the change in W:D is mainly caused by changes in depth. The relationship of bat mass and bell hole shape is apparent in Fig. 4. The narrow, deep holes always have fewer bats; the wider bell holes may or may not have more bats.

The wider, shallower holes (higher W:D ratio) can house many bats but they do not retain the heat. The very narrow (low W:D ratio) holes can only house a few bats. The optimum bell hole shape is a moderately wide and moderately deep hole that can house 10 bats or more but does not lose heat quickly. Temperature difference shows

Table 3

2-tailed, unpaired $T$-test results

\begin{tabular}{llll}
\hline & Difference & Probability* & $\begin{array}{l}\text { Significantly } \\
\text { different? }\end{array}$ \\
\hline $\begin{array}{c}\text { Temperature at lip: without bats } \\
\text { versus with bats }\end{array}$ & $+0.01{ }^{\circ} \mathrm{C}$ & 0.92 & No \\
$\begin{array}{c}\text { Temperature at top: without bats } \\
\text { versus with bats }\end{array}$ & $+1.00{ }^{\circ} \mathrm{C}$ & $9 \times 10^{-7}$ & Yes \\
$\begin{array}{c}\text { Temperature at top versus lip for } \\
\text { bell holes without bats }\end{array}$ & $+0.11{ }^{\circ} \mathrm{C}$ & 0.39 & No \\
$\begin{array}{c}\text { Temperature at top versus lip for } \\
\text { bell holes with bats }\end{array}$ & $+1.10{ }^{\circ} \mathrm{C}$ & $5 \times 10^{-8}$ & Yes \\
\hline
\end{tabular}

* Probability that temperature difference is not significantly different from zero.
Bellholes with $>0.3 \mathrm{~kg}$ bats

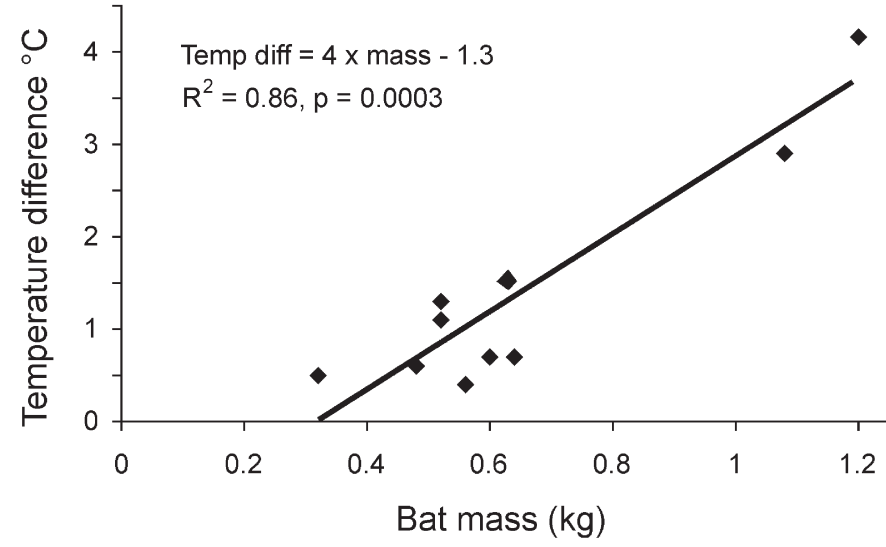

Fig. 3. Relationship of temperature difference between lip and apex of bell hole with bat mass.

the strongest relationship with bat mass for those bell holes with the optimum shape. Fig. 5 shows this for bell holes of W:D ratio in the intermediate range of 0.8 to 1.6 .

Putting these relationships together on a 3-D graph (Fig. 6) shows the highest temperature difference for the higher bat masses but most significantly for holes of W:D ratio between 0.8 and 1.6.

\subsection{Empirical observations: rate of temperature decay}

The second part of the empirical observations was a measurement of the rate of change of rock temperature for one bell hole after bats had exited. The bell hole had 42 Artibeus bats (mass $630 \mathrm{~g}$ ) and was at a temperature of $27.0{ }^{\circ} \mathrm{C}$ (ambient cave temperature of $25.5{ }^{\circ} \mathrm{C}$ ). Temperature decay after removal of bats (Fig. 7) is exponential, and highly significant $\left(p=1 \times 10^{-6} ; r^{2}=0.94\right)$. Temperature would return to ambient after approximately $5 \mathrm{~h}$, indicating that, even in this very hot example, the bell hole has enough time to return to ambient temperature before the return of the bats in about $6 \mathrm{~h}$. Thus the rock temperature returns to normal each day.

\subsection{Modelling impacts of bat metabolism}

For the purposes of modelling we assume a typical bell hole apex diameter of $0.30 \mathrm{~m}$ and depth of $1.00 \mathrm{~m}$. The surface area of the apex is $\sim 0.07 \mathrm{~m}^{2}$ and the volume of space inside the bell hole $\sim 0.07 \mathrm{~m}^{3}$. If we

\section{Bat mass v. shape of bellholes}

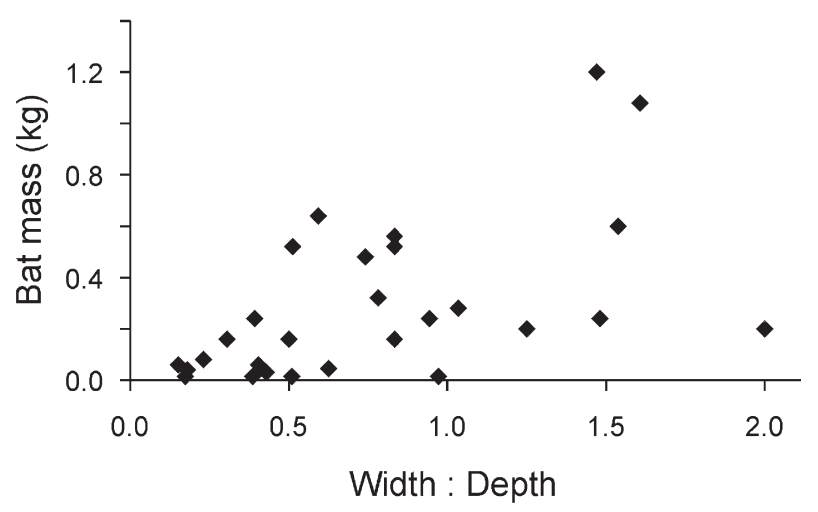

Fig. 4. Relationship of bat mass with shape of bell holes as expressed by the Width: Depth ratio. 
Bellholes of W/D range: 0.8 to 1.6

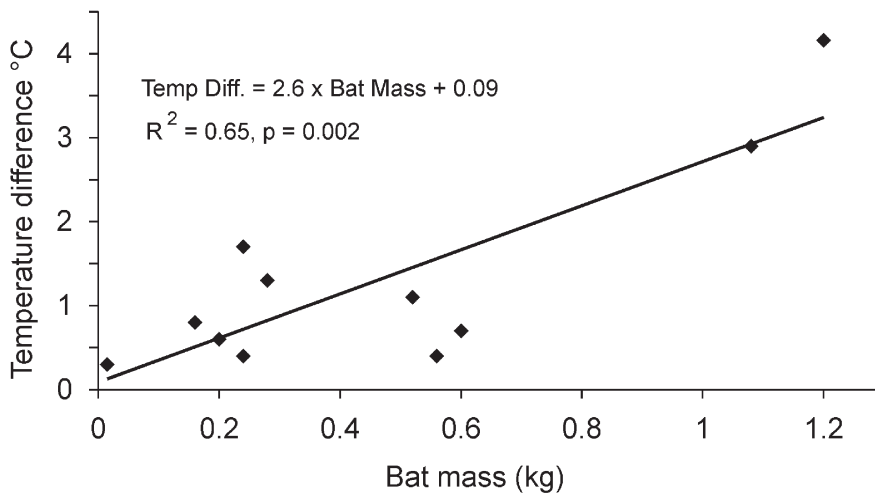

Fig. 5. Relationship of temperature difference between lip and apex of bell hole and mass of bats, but only for bell holes that are moderately deep (neither shallow nor very deep).

assume a bat population of 10 Artibeus, each of $40 \mathrm{~g}$ body mass, then the total bat mass is $400 \mathrm{~g}$. A standard roost time is $18 \mathrm{~h}$ of each day. The typical output of $\mathrm{CO}_{2}$, water vapour, and heat can be calculated from known rates (Table 4 ).

- The basic metabolic rate (BMR) is $2.89 \mathrm{~cm}^{3} \mathrm{O}_{2} / \mathrm{g}$ bat/h (McNab, 1969, for Carollia perspicallata, a comparable neotropical frugivorous bat, closely related and almost identical in feeding and general ecology to $A$. jamaicensis). $\mathrm{O}_{2}$ input equals $\mathrm{CO}_{2}$ output by volume. This can be expressed by weight instead, as $0.00568 \mathrm{~g} \mathrm{CO}_{2} / \mathrm{g}$ bat/h. So $400 \mathrm{~g}$ of bat will produce $\sim 41 \mathrm{~g} \mathrm{CO}_{2}$ per 18 hour roost period.

- Bat body temperature is $36.4^{\circ} \mathrm{C}$. The basic energy expenditure (EE) is $58 \mathrm{~J} / \mathrm{g}$ bat/h. So $400 \mathrm{~g}$ of bat will produce $417.6 \mathrm{~kJ}$ per 18 hour roost period.

- Evaporative water loss (EWL) is given in $\mathrm{g}_{2} \mathrm{O}$ averaged over $24 \mathrm{~h}$ : Log of evaporative water loss $=\operatorname{Ln}(0.398)+0.672 * \operatorname{Ln}$ (bat mass). This is recalculated for each hour. So $400 \mathrm{~g}$ of bat will produce $35.6 \mathrm{~g} \mathrm{H}_{2} \mathrm{O}$ per $18 \mathrm{~h}$ roost period. Dewpoint calculations show that bat breath at $36{ }^{\circ} \mathrm{C}$ and $95 \%$ relative humidity (RH) would have a dewpoint of $35^{\circ} \mathrm{C}$. This is well above the average temperature at the top of the bat-occupied bell holes $\left(26.4{ }^{\circ} \mathrm{C}\right)$ and even the temperature of the hottest $\left(28.5^{\circ} \mathrm{C}\right)$. Thus, we would expect bat breath to condense at the top and on the walls of the bell hole.

So far we have established that a modest population of 10 bats will produce relatively large outputs of heat, $\mathrm{CO}_{2}$, and water. The $\mathrm{CO}_{2}$

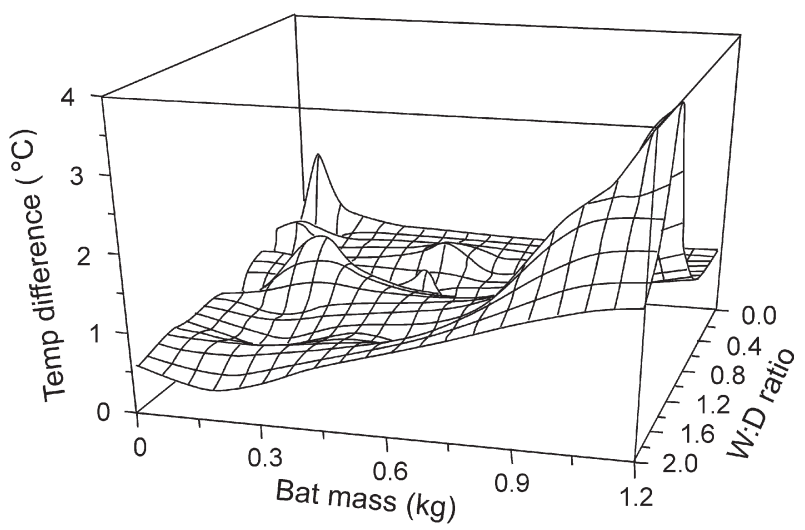

Fig. 6. 3-D graph of temperature difference between lip and apex of bell hole plotted against bat mass and bell hole shape.
Temperature decay

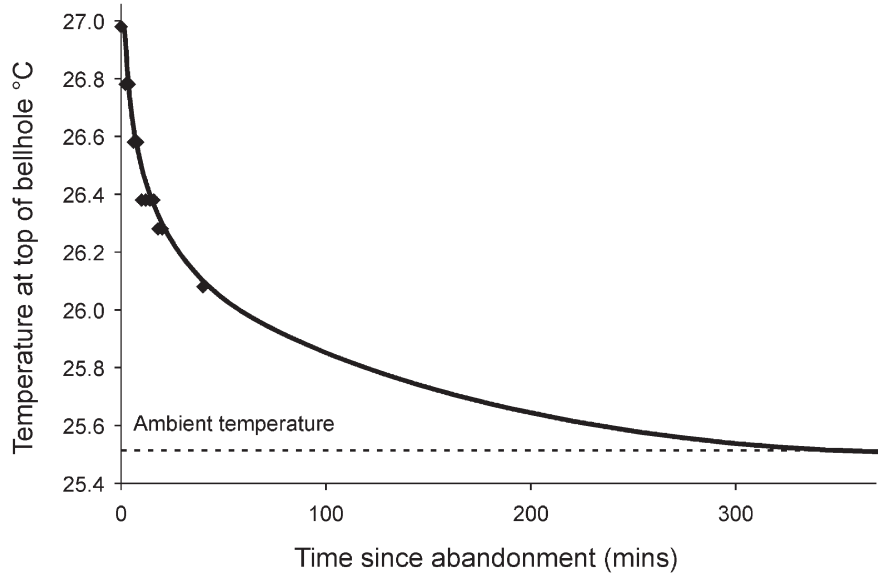

Fig. 7. Rate of temperature decay after abandonment of bell hole, and propagation of rate to ambient temperature (about $5 \mathrm{~h}$ ).

dissolves in the water film, creating a slightly acidic carbonic acid solution, and limestone dissolution can proceed as normal.

The next stage of the modelling exercise is to estimate the impact of this metabolic activity on rock dissolution. The variables that control rates of dissolution in water films are water volume and aggressivity, and solvent and solute removal rates.

- Thickness of water film: the $35.6 \mathrm{~g} \mathrm{H}_{2} \mathrm{O}$ water vapour will condense because the rock temperature is always below the dew point. If we assume a distribution concentrated around the bat faces and bodies, that is the apex of the bell hole to about $10 \mathrm{~cm}$ down the walls, then the surface area of rock wetted by bat breath is $0.08 \mathrm{~m}^{2}$. If all of the water ( $35.6 \mathrm{~g}$ or $0.04 \mathrm{l}$ ) condenses (we can expect little evaporation in the high humidity that characterizes the tops of the bell holes during roosting), then a water film of $0.44 \mathrm{~mm}$ thickness will form by the end of one 18 hour bat roost day. This thin water film will allow relatively rapid dissolution of $\mathrm{CO}_{2}$, open system dissolution, and rapid diffusion throughout.

- Aggressivity of water: dissolution of $\mathrm{CO}_{2}$ in the water film (the majority of which requires only a few moments; see Bögli, 1980) is the most likely control on aggressivity (ignoring any potential additional impact of other acidic metabolites). Because of the temperature gradient, the $\mathrm{CO}_{2}$, although of higher mass than $\mathrm{O}_{2}$ and $\mathrm{N}_{2}$, is warm enough to avoid falling out of the bell hole (but it does not need to remain at the top of the bell hole for long because it will be dissolved rapidly). The bell hole volume is $0.07 \mathrm{~m}^{3}$. If all of the $0.0208 \mathrm{~m}^{3} \mathrm{CO}_{2}$ produced in one roost day remains inside the bell hole, then the bell hole atmosphere would be $29.7 \% \mathrm{CO}_{2}$. This is too high for two reasons: 1) although once the bats settle to roost, circulation rates drop and humidity rapidly rises to $100 \%$, we can expect some exchange with the cave air; and 2) although bats, like many small mammals, are quite tolerant of hypercapnic conditions

Table 4

Production of $\mathrm{CO}_{2}$, heat and water vapour from a colony of 10 Artibeus bats, assuming an 18 hour-roost day

\begin{tabular}{llll}
\hline & Carbon dioxide & Heat & Water Vapour \\
\hline Basic data & $\begin{array}{l}0.00568 \mathrm{~g} \mathrm{CO}_{2} / \mathrm{g} \text { bat } / \mathrm{h} \\
\left(2.89 \mathrm{~cm}^{3} \mathrm{CO}_{2} / \mathrm{g} \mathrm{bat} / \mathrm{h}\right)\end{array}$ & $\begin{array}{l}0.058 \mathrm{~kJ} / \mathrm{g} \\
\text { bat/h }\end{array}$ & $\begin{array}{l}\text { (LOG }(0.398))+0.672 * \mathrm{LOG} \\
\text { (bat mass) }\end{array}$ \\
$\begin{array}{c}\text { Output from } 400 \mathrm{~g} \\
\begin{array}{c}2.271 \mathrm{~g} \mathrm{CO}_{2} / \mathrm{h} \\
\text { of bats per hour }\end{array}\end{array}$ & $23.2 \mathrm{~kJ} / \mathrm{h}$ & $1.98 \mathrm{~g} \mathrm{H}_{2} \mathrm{O} / \mathrm{hr}$ \\
$\begin{array}{l}\left(1156 \mathrm{~cm}^{3} \mathrm{CO}_{2} / \mathrm{h}\right) \\
\text { Output in 18 h day }\end{array}$ & $\begin{array}{l}40.873 \mathrm{~g} \mathrm{CO}_{2} \\
\left(20808 \mathrm{~cm}^{3} \mathrm{CO}_{2}\right)\end{array}$ & $417.6 \mathrm{~kJ}$ & $35.6 \mathrm{~g} \mathrm{H}_{2} \mathrm{O}$ \\
Output per year & $14.918 \mathrm{~kg} \mathrm{CO}_{2}$ & $152424 \mathrm{~kJ}$ & $12.996 \mathrm{~kg} \mathrm{H}_{2} \mathrm{O}$ \\
\hline
\end{tabular}


(high $\mathrm{CO}_{2}$ levels), we would not expect levels much higher than $5 \%$. This estimate is based on several reports of hypercapnic conditions: e.g., Baudinette et al. (1994) report that even in open-cave bat roosts hypercapnic conditions develop, e.g., $0.35 \% \mathrm{CO}_{2}$, a ten-fold increase over normal atmospheric levels (0.03\%). We found no data on more confined situations in caves, but Shams et al. (2005) report that naked mole rats, in confined conditions that might be comparable with bell holes, tolerate at least $6.1 \% \mathrm{CO}_{2}$. Using White's Fig. 5.2, (White, 1988: p.131, curve for $20^{\circ} \mathrm{C}$ ) and assuming saturation at $5 \%$ $\mathrm{CO}_{2}$ or $P \mathrm{PO}_{2}$ of $0.5 \times 10^{-1} \mathrm{~atm}$, the water film will contain $\sim 350 \mathrm{mg} / \mathrm{L}$ $\mathrm{CaCO}_{3}$ and its $\mathrm{pH}$ would be $\sim 6.8$. So $0.036 \mathrm{l}$ of water at $350 \mathrm{mg} / \mathrm{L}$ is a total of $12.6 \mathrm{mg} \mathrm{CaCO}_{3}$ per day. At a density of 2.5 , this translates to $0.005 \mathrm{~cm}^{3} \mathrm{CaCO}_{3}$ per day, and $1.84 \mathrm{~cm}^{3}$ per year. If this loss is applied to the apex and topmost $10 \mathrm{~cm}$ surface $\left(0.08 \mathrm{~m}^{2}\right.$ or $\left.800 \mathrm{~cm}^{2}\right)$, then the surface reduction can be estimated at $0.023 \mathrm{~mm}$ per year or $23 \mathrm{~mm}$ per kyr. If the bell hole is $1 \mathrm{~m}$ deep $(1000 \mathrm{~mm})$, then 43,489 years are required from this mechanism alone. Obviously this estimate is governed by the concentrations of $\mathrm{CO}_{2}$ : if we use $10 \% \mathrm{CO}_{2}$ then 32,674 years are required; if we use $1 \%$, then 90,761 years are required. We assume that somewhere around $50 \mathrm{kyrs}$ is a reasonable estimate for rate of bell hole development if it were by this process alone. It is of relevance to note that many of the limestones of tropical regions have up to $30 \%$ porosity and thus are of less than 2.5 average density. If we assume that the density is reduced by $25 \%$ then the estimate of time required is reduced to $\sim 23,000$ years.

- Solvent and solute removal rates are not easy to estimate and for this research no measurements were attempted. A mechanism for removal of the products of dissolution does not seem immediately obvious in that most bell holes do not have obvious flutes down the walls indicating water flow, nor are they seen to drip from the edges. Removal of some saturated water on/by feet and wings of bats during exodus is assumed. We can assume that most of the warm, wet air from the bell hole is displaced during bat exodus by dry, cool air: the bat wing action necessary to support the $400 \mathrm{~g}$ of bat displaces several bell hole volumes of air within only a few seconds. Norberg (1976) offers data on body measurements and flight parameters for hovering flight in the bat Plecotus auritus (of typical mass $10 \mathrm{~g}$ ). Based on the wing area, stroke rate, and induced wind, each bat displaces $\sim 0.01 \mathrm{~m}^{3} /$ second. Thus we can expect the $400 \mathrm{~g}$ of bats in our hypothetical bell hole to displace approximately $0.4 \mathrm{~m}^{3} /$ second. The bell hole volume is only $0.07 \mathrm{~m}^{3}$. Thus the whole bell hole air volume would be displaced within the first second of bat flight. The calcite saturated water that remains after bat exodus is presumed to evaporate and the contained calcite to deposit in the form of a powder on the rock surface. In Runaway Bay Caves and

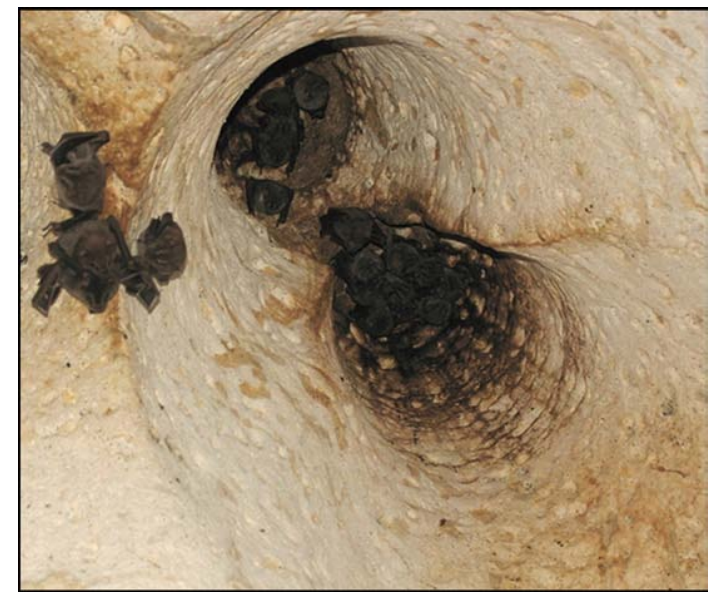

Fig. 8. A double bell holes with roosting Artibeus jamaicensis. Note black staining of sides. Photograph by Keith Christensen, reproduced with permission. several other caves in Jamaica, the tops of many bell holes, where the bats feet attach during roosting, are observed to be bare rock, while the sides may have varying amounts of organic staining (some enough to run down the sides in small rivulets, Fig. 8), some crust., etc. So we assume that bats claws keep the apex surface clean, removing any powdery, re-deposited calcite. Solvent replacement is simple: each evening the bats' exodus causes a strong mixing of the cave air (unpublished data collected by the authors from Jamaica and Kenya), removing the humid, $\mathrm{CO}_{2}$-rich air from the bell holes. Heat energy is lost throughout the evening. The return of the bats to roost once again introduces heat, water vapour and $\mathrm{CO}_{2}$ to the top of the bell hole to start the diurnal cycle afresh.

- The impact of the metabolic heat production governs the location of maximum dissolution. Heat output increases air stability: the hot, $\mathrm{H}_{2} \mathrm{O}-\mathrm{CO}_{2}$-rich air in the bell hole remains within the concavity and ensures that the focus of corrosion is vertically upwards.

\section{Discussion}

The hypothesis that bell holes are the result of inadvertent niche changing by non-colonial, clustering bat roosting does appear to explain their features well.

We have demonstrated that the mere presence of bats modifies the microclimate such that enhanced rock dissolution can occur. While any concentrations of bats will produce sufficient $\mathrm{CO}_{2}$, heat, and water to affect the cave microclimate and effect enhanced dissolution of rock surfaces, it is only where that influence is focused that bell holes will form. This sets up a kind of positive feedback system whereby, over time, differential dissolution deepens the negative forms and provides more sheltered niches for the bats, enhancing the attractiveness of the site for bats. This is an example of niche changing on a tiny scale but, accumulated over millennia, is sufficient to produce significant negative forms.

We have investigated only the potential effect on dissolution. Another obvious implication of the microclimate modification is that each bell hole site is also rendered more attractive for other forms of biological activity, largely bacterial but perhaps including epilithithic or endolithic fungi. The ubiquitous brown-black crust that exfoliates regularly has not been studied here, but is likely to represent the breakdown products of rock alteration in addition to external inputs from bat-derived organics (see Onac et al., 2001). We suggest that the rock surface is altered by a suite of organic processes some of which may relate directly to excreta of bats, but that most of the surface is probably an organic-rock complex of bacterial origin. Addition of such erosional mechanisms would accelerate the rate of formation.

Bell holes are initiated by bat choice of roost sites, which in turn is usually governed by competition for space and random or nonrandom inhomogeneities in the cave roof. In the case of Runaway Bay Caves, sites are governed by the pattern of post-speleogenetic pocketing or phreatic scalloping inherited from speleogenesis. Once the initial site has become established it is likely that other modes of biogenically-enhanced erosion will accelerate bell hole formation, such that the majority of bell holes have probably formed in less than the requisite 50 kyrs.

Bell hole width is probably a function of the optimum number of bats that will congregate together. This varies with species (for example, bats like Artibeus form harems so that colony size is selflimited) and may vary over time but the implication is that, if the same species continues to colonize the one cave, the bell holes will generally have similar diameters. Bell hole depth might be limited by bats' tolerance for hypercapnic conditions: the deeper the hole, the less exchange with open cave air and the higher the $\mathrm{CO}_{2}$ concentration. However, very deep bell holes presumably make flight increasingly awkward, and so may discourage occupation if shallower holes are available. Once bats abandon a deep hole, it no longer receives the diurnal inputs and exchanges that allow continued enlargement. 
The implication of this research is that bell holes will not form in all caves with bats; rather that bell holes are more likely to be associated with non-colonial bats that roost only in small clusters. Thus we can expect bell holes to form only in those climates and geographic areas that favour clustering bats. Other tropical bat species occur in large numbers in caves but form uniform distributions across the roofs; we would predict these cave passages not to have bell holes.

Bell hole distribution within cave is controlled by distribution of the clustering bats. Distribution of bell holes and distribution of clustering bats seems to be inter-related in that both are observed mainly in entrance zones and in shallow caves: certainly Artibeus is an entrance zone rooster. However, some of the clustering bats may penetrate deeper into the caves and we have not done exhaustive surveys to be sure that bell holes are indeed limited to entrance zones. Bell holes themselves are more attractive to clustering bats than to non-clustering bats: the non-clustering species do not like bell hole areas because, being more social, they cannot form continuous mats of bats on roofs with bell holes. Non-clustering bats do not need the relative warmth of a bell hole because the whole passage is heated by the large mass of bats.

Clustering bats are not restricted to tropical regions, so the apparent restriction of bell holes to tropical regions must also be explained. We have seen that, in the study area, significant impacts are apparent only if the bat mass is above $300 \mathrm{~g}$. We suggest that small clusters of bats in temperate regions roosting adjacent to rock at perhaps $6{ }^{\circ} \mathrm{C}-12{ }^{\circ} \mathrm{C}$ do not make enough difference to the microclimate and that the warmed air is cooled too quickly to form a stable pool. For example, grey bats of temperate areas such as Kentucky cluster together for heat, but do not significantly raise the temperature of the passage (Tuttle, 1976). Temperate hibernating bats have little or no impact on roost microclimate, since they go into torpor and reduce their own body temperature to near-ambient (Hock, 1951; Henshaw and Folk, 1966).

Obviously another implication of this hypothesis is that bell holes should not form in caves without bat-sized entrances. Unfortunately this may be impossible to test since we cannot know of all the $\sim 5 \mathrm{~cm}$ sized entrances that may exist before any human-sized entrance opens up to allow us access to the cave.

Tarhule-Lips and Ford (1998b) convincingly demonstrate that condensation corrosion is an important process in the entrance zones of some tropical caves. However, they (1998b) do not convincingly demonstrate that it can be focused to produce bell holes. Our hypothesis is essentially that bell holes form through bat-mediated condensation corrosion focused on points chosen by bats. Our model provides a mechanism for initiation of the hole, and continued focusing of corrosion on the same hole. It also explains how heat is dissipated diurnally such that the process can be maintained indefinitely.

The estimate of 50,000 years for formation is probably far too conservative in view of the low density of tropical limestones and the very likely influence of other biogenic processes to the erosion. In reality it may be more realistic to assume a considerably shorter time frame - perhaps some 25,000 years. However, another consideration is that the full effect of the bat-mediated condensation corrosion will not operate while the concavity is shallow. The bell hole already has a head start because the bats roost in a pre-existing concavity. This research shows that the effect of bat metabolic activity is measurable and statistically significant for the larger forms and the larger bat populations. However, this does not imply that there is no effect for the smaller forms and smaller bat populations - it is simply less. Thus we feel that the 50,000 year estimate is a reasonable timeframe to both start and develop a $1 \mathrm{~m}$ deep bell hole.

\section{Conclusion}

The impact of bat presence on the temperature of bell holes in Runaway Bay Caves, Jamaica, was measured and the potential impact of their metabolism on dissolution processes modelled. The results were applied to a discussion of bell hole formation rates and mechanisms. We conclude that:

- bell holes with bats get significantly hotter than those without bats during bat roosting periods;

- temperature difference between tops and lips shows the clearest relationship for bell holes with more than about $300 \mathrm{~g}$ bat body mass ( 10 bats);

- temperature difference between tops and lips shows the clearest relationship for moderately deep and wide bell holes, of intermediate $\mathrm{W}: \mathrm{D}$ ratio between 0.8 and 1.6 ;

- rock temperature returns to normal each day during bat foraging periods - temperatures in even the hottest bell holes return to ambient after approximately $5 \mathrm{~h}$;

- basic metabolic activity of $\sim 10$ bats (400 g) will produce $41 \mathrm{~g} \mathrm{CO}_{2}$, $417.6 \mathrm{~kJ}$, and $35.6 \mathrm{~g} \mathrm{H}_{2} \mathrm{O}$ in each 18 hour roost period;

- this will produce at the top of the bell hole an atmosphere with $5 \%$ or more $\mathrm{CO}_{2}$, and an estimated $0.44 \mathrm{~mm}$-thick water film that dissolves $350 \mathrm{mg} / \mathrm{L} \mathrm{CaCO}_{3}$;

- this translates to removal of $0.005 \mathrm{~cm}^{3} \mathrm{CaCO}_{3}$ per day, and a surface reduction at the top of the bell hole of $0.023 \mathrm{~mm}$ per year or $23 \mathrm{~mm}$ per kyr;

- some 50,000 years are required to create a bell hole $1 \mathrm{~m}$ deep from this mechanism alone;

- additional bio-chemical corrosion that results in the dark-coloured crusts probably accelerate their rate of development;

- rising heat ensures that convection overrides geologic control on the vertical orientation;

- location of bell hole is governed by choice of roost site;

- this example of bats modifying their micro-climatic and physical environment represents an example of niche changing on a small scale.

We predict that bell holes will be associated with clustering bats rather than colonial bats and that the geographic distribution of bell holes is governed by both climate and clustering bat distribution.

This model offers a quantitative argument to support the anecdotal evidence of the association of bell holes and bats; it provides a causative mechanism for both the initiation and the continuation of the discrete, focussed erosion that is required to produce bell holes; and it yields a plausible time frame for formation.

\section{Acknowledgements}

Fieldwork was carried out with the permission of the Management, Runaway bay caves, Jamaica. We thank Guy van Rentergem and Stefan Stewart of the Jamaica Caves Organization for assistance in the field. We are grateful to Keith Christenson for further field assistance and permission to use his photographs.

\section{References}

Bakken, G.S., Kunz, T.H. 1988. Microclimate methods. In: Kunz, T.H. (Ed.), Ecological and Behavioral Methods for the Study of Bats. Smithsonian Institution Press, Washington, pp. 303-332

Baudinette, R.V., Wells, R.T., Sanderson, K.J., Clark, B., 1994. Microclimatic conditions in maternity caves of the bent-wing bat, Miniopterus schreibersii: an attempted restoration of a former maternity colony. Wildlife Research 21, 607-619.

Bögli, A., 1980. Karst hydrology and Physical Speleology. Springer-Verlag, Berlin.

Dawkins, R., 2004. Extended phenotype - but not too extended. A reply to Laland, Turner and Jjablonka. Biology and Philosophy 19, 377-396.

Dogwiler, T.J., 1998. Analysis of bell hole morphology and distribution: a tool for evaluating formational processes. Unpublished MSc Thesis Mississippi State University.

Dwyer, P.D., Hamilton-Smith, E., 1975. Breeding caves and maternity colonies of the bent-wing bat in southeastern Australia. Helictite 4, 3-21.

Henshaw, R.E., Folk, G.E., 1966. Relation of thermoregulation to seasonally changing microclimate in two species of bats (Myotis lucifugus and M. sodalist). Physiological Zoology 39, 61-70.

Hock, R.J., 1951. The metabolic rates and body temperatures of bats. Biological Bulletin 101, 289-299. 
Ige, D.V., Akinyemi, O.O., Nyachoti, C.M., Gunther, W., 2006. Phosphorus fractions in manure from growing pigs receiving diets containing micronized peas and supplemental enzymes. Journal of Environmental Quality 35, 390-396.

Jones, D., 2005. Personal Effects. (News feature). Nature 438 (7064), 14-16.

Kadlubar, F.F., Unruh, L.E., Flammang, T.J., Sparks, D., Mitchum, R.K., Mulder, G.J., 1981 Alteration of urinary levels of the carcinogen, $\mathrm{N}$-hydroxy-2-naphthylamine, and its $\mathrm{N}$-glucuronide in the rat by control of urinary $\mathrm{pH}$, inhibition of metabolic sulfation, and changes in biliary excretion. Chemico-Biological Interactions 33,129-147.

King-Webster, W.A., Kenny, J.S., 1958. Bat erosion as a factor in cave formation. Nature $181,1813$.

Kunz, T.H., 1974. Feeding ecology of a temperate insectivorous bat (Myotis velifer). Ecology 55, 693-711.

Kunz, T.H., 1980. Daily energy budgets of free-living bats. In: Wilson, D.E., Gardner, A.L. (Eds.), Proc. 5th International Bat Research Conference. Texas Tech Press, Lubbock, pp. 369-392.

Kunz, T.H., Robson, S.K., 1995. Postnatal growth and development in the mexican freetailed bat (Tadarida brasiliensis mexicana): birth size, growth rates, and age estimation. Journal of Mammalogy 76 (3), 769-783.

Lauritzen, S.-E., Lundberg, J., 2000. Solutional and erosional morphology. In: Klimchouk, A.B. Ford, D.C., Palmer, A.N., Dreybrodt, W. (Eds.), Speleogenesis: Evolution of Karst Aquifers. National Speleological Society, Huntsville, AL, United States (USA), pp. 408-426.

Lauritzen, S.-E., Lundberg, J., Mylroie, J.E., Dogwiler, T., 1997. Bell hole morphometry of a flank margin cave and possible genetic models: Lighthouse Cave, San Salvador, Bahamas. Proceedings of the 12th International Congress of Speleology, Neuchatel, Switzerland, 11-17 Aug 1997.

Lundberg, J., 2005. Karren. In: Culver, D., White, W. (Eds.), Encyclopedia of Caves. Elsevier, Amsterdam, pp. 315-321.

McNab, B.K., 1969. The economics of temperature regulation in neotropical bats. Comparative Biochemistry and Physiology 31, 227-268.

McNab, B.K., 1974. The behavior of temperate cave bats in a subtropical environment. Ecology 55 (5), 943-958.

Miller, T., 1981. Hydrochemistry, hydrology, and morphology of the Caves Branch Karst, Belize. Unpublished PhD Thesis, McMaster University, Hamilton, Ontario, Canada, 280 pp.

Miller, T., 2006. Bell holes and Bellbasins: biogenic (bat) features of Caribbean Caves. GSA Annual Meeting, Philadelphia, 2006, Abstracts with Program, 63.

Norberg, U.M., 1976. Aerodynamics of hovering flight in the long-eared bat Plecotus auritus. Journal of Experimental Biology 65, 459-470.
Onac, B.P., White, W.B., Mylroie, J., 2001. Mineralogy of cave deposits on San Salvador Island, Bahamas. Carbonates and Evaporites 16, 8-16.

Pedersen, S.C., Genoways, H.H., 1996. Notes on bats from Montserrat (Lesser Antilles) with comments concerning the effects of Hurricane Hugo. Caribbean Journal of Science 32, 206-213.

Ransome, R., 1990. The Natural History of Hibernating Bats. Christopher Helm, London. $235 \mathrm{pp}$.

Rivera-Marchand, B., Rodríguez-Durán, A., 2001. Preliminary observations on the renal adaptations of bats roosting in hot caves in Puerto Rico. Caribbean Journal of Science 37, 272-274.

Rodríguez-Durán, A., 1998. Nonrandom aggregations and distribution of cave-dwelling bats in Puerto Rico. Journal of Mammalogy 79, 141-146.

Shams, I., Aviviv, A., Nevo, E., 2005. Oxygen and carbon dioxide fluctuations in burrows of subterranean blind mole rats indicate tolerance to hypoxic and hypercapnic stresses. Comparative Biochemistry and Physiology. A. Comparative Physiology 142, 376-382.

Sweeting, M.M., 1958. The karstlands of Jamaica. Geographical Journal 124, 184-199.

Tarhule-Lips, R.F.A., Ford, D.C., 1997. Morphologic studies of bell hole development on Cayman Brac. Proceedings of the International Congress of Speleology, vol. 12, p. 146

Tarhule-Lips, R.F.A., Ford, D.C., 1998a. Morphometric studies of bell hole development on Cayman Brac. Cave and Karst Science 25 (3), 19-130.

Tarhule-Lips, R.F.A., Ford, D.C., 1998b. Condensation Corrosion in caves on Cayman Brac and Isla de Mona. Journal of Cave and Karst Studies 60, 84-95.

TutTarhule-Lipse, M.D., 1975. Population ecology of the gray bat (Myotis grisescens): factors influencing early growth and development. Occasional Papers Museum Natural History University of Kansas 36, 1-24.

Tuttle, M.D., 1976. Population ecology of the gray bat (Myotis grisescens): philopatry timing, and patterns of movement, weight loss during migration, and seasonal adaptive strategies. Occasional Papers Museum Natural History University of Kansas $54,1-38$.

Vaughan-Jennings, N., Parson, S., Barlow, K.E., Gannon, M.R., 2004. Echolocation calls and wing morphology of bats from the West Indies. Acta Chiropterologica 6 (1), 75-90.

White, W.B., 1988. Geomorphology and Hydrology of Karst Terrains. Oxford University Press, New York, Oxford. 464 pp.

Wilford, C.E., 1966. "Bell holes" in Sarawak Caves. Bulletin of the National Speleological Society $28,179-182$. 